\title{
PENGHINDARAN PAJAK PADA INDUSTI BARANG KONSUMSI DI INDONESIA SEBELUM ERA PANDEMI COVID19: UKURAN PERUSAHAAN DAN PROFITABILITAS
}

\author{
Jeremi Martinus $^{1)}$; Mellida Ema Jiwandaningtyas ${ }^{2)}$; Amrie Firmansyah ${ }^{3{ }^{*}}$; Arifah Fibri Andriani ${ }^{4)}$ \\ 1) jeremimartinus13@gmail.com, Politeknik Keuangan Negara STAN \\ 2) emamellida@gmail.com, Politeknik Keuangan Negara STAN \\ 3) amrie@pknstan.ac.id, Politeknik Keuangan Negara STAN \\ 4) arifahfibri@pknstan.ac.id, Politeknik Keuangan Negara STAN \\ *penulis korespondensi
}

\begin{abstract}
This study aims to analyze firm size and profitability on tax avoidance. This research data is sourced from the financial statements of companies in the consumer goods industry sector listed on the Indonesia Stock Exchange (IDX). The data was obtained from www.idx.co.id. The total research sample based on purposive sampling is 96 observations consisting of 32 companies from 2017 to 2019. Hypothesis testing is carried out by using multiple regression analysis tests for panel data. The result suggests that firm size and profitability are positively associated with tax avoidance. This research indicates that the Indonesian tax authorities need to consider companies with a high level of related operating performance and large assets concerning tax avoidance policies.
\end{abstract}

Keywords: Taxes, Total Assets, Net Income, Firm Characteristics

\begin{abstract}
Abstrak
Penelitian ini bertujuan untuk menganalisis pengaruh ukuran perusahaan dan profitabilitas terhadap penghindaran pajak. Data penelitian ini bersumber dari dari laporan keuangan perusahaan sektor industri barang konsumsi yang terdaftar di Bursa Efek Indonesia (BEI). Data penelitian diperoleh dari www.idx.co.id. Total sampel penelitian berdasarkan purposive sampling berjumlah 96 observasi yang terdiri dari 32 perusahaan dari tahun 2017 sampai dengan tahun 2019. Pengujian hipotesis dilakukan dengan uji analisis regresi berganda untuk data panel. Hasil penelitian menunjukkan bahwa ukuran perusahaan dan profitabilitas berpengaruh positif terhadap penghindaran pajak. Penelitian ini mengindikasikan bahwa otoritas pajak Indonesia perlu mempertimbangkan perusahaan dengan tingkat kinerja operasi yang tinggi terkait dan aset yang besar, terkait dengan dengan kebijakan penghindaran pajak.
\end{abstract}

Kata Kunci: Pajak, Total Aset, Laba Bersih, Karakteristik Perusahaan

\section{PENDAHULUAN}

Pajak merupakan bentuk kontribusi wajib warga negara atau badan kepada suatu negara (Republik Indonesia, 2007). Penerimaan pajak digunakan untuk membiayai pelaksanaan fungsi pemerintah meliputi pembangunan infrastruktur, pendidikan dan fungsi lain guna meningkatkan kesejahteraan masyarakat (Mankiw, 2012). Pajak memegang peranan penting dalam mendanai perekonomian suatu negara. Pajak merupakan sumber penerimaan terbesar pada postur Anggaran Pendapatan dan Belanja Negara (APBN). Pada tahun 2018, 2019, dan 2020, pajak mendominasi penerimaan negara sebesar rata-rata $80 \%$ dari keseluruhan penerimaan negara. Namun, target pajak pemerintah tidak pernah tercapai dalam 10 tahun terakhir (Victoria, 2020).

Pada umumnya, wajib pajak baik orang pribadi maupun badan memiliki kecenderungan untuk memperkecil jumlah pajak yang dibayarkan kepada otoritas pajak (Pajriansyah \& Firmansyah, 2017). Salah satu upaya wajib pajak badan untuk menurunkan kewajiban perpajakan adalah melalui penghindaran pajak (Falbo \& Firmansyah, 2018). Penghindaran pajak merupakan salah satu strategi perusahaan dengan memanfaatkan celah dalam peraturan perundangan dengan tujuan untuk mengurangi kewajiban perpajakan. Tindakan ini tidak melanggar ketentuan perundangan terkait dengan perpajakan, namun berlawanan dengan tujuan utama dipungutnya pajak (Manurung, 2020).

Aktivitas penghindaran pajak selain antara lain disebabkan oleh perbedaan kepentingan 


\section{EDUCORETAX}

Volume 1 No. 4, Desember 2021

antara perusahaan dengan pemerintah dan kurangnya insentif yang disediakan oleh pemerintah (Mughal \& Akram, 2012). Tindakan penghindaran pajak banyak dilakukan oleh perusahaan sebagai usaha pengurangan kewajiban perpajakan tanpa melanggar ketentuan perpajakan (Pramudya et al., 2021). Tindakan penghindaran pajak dilakukan dengan memanfaatkan aktivitas-aktivitas yang belum diatur dalam ketentuan peraturan perundangan terkait dengan perpajakan (Pramudya et al., 2021).

Tindakan manajer dalam melakukan penghindaran pajak dapat menurunkan kepercayaan pemilik perusahaan. Aktivitas penghindaran pajak dilakukan oleh manajer terkait dengan penghematan pajak dengan tujuan mendapatkan laba operasi yang lebih besar. Adanya informasi asimetri mengakibatkan manajer dapat memiliki kebijakan yang tidak diketahui oleh pemegang saham. Manajer dapat memanfaatkan kondisi tersebut untuk melakukan tindakan sesuai dengan motif-motif tertentu. Selain itu, walaupun tidak melanggar ketentuan dan perundangan perpajakan, tindakan penghindaran pajak masih memungkinkan adanya potensi sengketa yang terjadi antara perusahaan dan otoritas perpajakan di masa depan. Manajer memiliki kebijakan dalam menjalankan operasi perusahaan yang mungkin berbeda dengan kepentingan pemegang saham. Oleh karena itu, pengujian penghindaran pajak perlu untuk diinvestigasi.

Arham et al. (2020) telah mengindentifikasi penelitian penghindaran pajak di Indonesia selama periode tahun 1999 sampai dengan tahun 2020. Arham et al. (2020) menggunakan data penelitian yang dipublikasikan pada jurnal terakreditasi Sinta dan Jurnal terindeks Scopus. Penelitian penghindaran pajak sebelumnya diuji dengan ukuran perusahaan (Annisa et al., 2017; Fitria \& Handayani, 2019; V. R. Putri \& Putra, 2017; Wardani \& Khoiriyah, 2018), kepemilikan institusional (Mulyani et al., 2018; R. D. Putri, 2018; Sari \& Devi, 2018; Zia et al., 2018), komite audit (Fitria \& Handayani, 2019; Mulyani et al., 2018; R. D. Putri, 2018; Sari \& Devi, 2018), leverage (Hidayat, 2018; Permata et al., 2018; Puspitasari et al., 2021; R. D. Putri, 2018; Wardani \& Khoiriyah, 2018), komisaris independen (Fitria \& Handayani, 2019; Mulyani et al., 2018; R. D. Putri, 2018; Sari \& Devi, 2018). Penelitian selanjutnya pengujian penghindaran pajak dilakukan dengan tax haven (Pramudya et al., 2021; Wijaya \& Rahayu, 2021), multinationality (Falbo \& Firmansyah, 2021; Pramudya et al., 2021), profitabilitas (Darmawan \& Sukartha, 2014; Dewinta \& Setiawan, 2016; Dwiyanti \& Jati, 2019; Kurniasih \& Sari, 2013; Puspitasari et al., 2021; V. R. Putri \& Putra, 2017; Yulianty et al., 2021), manajemen laba (Falbo \& Firmansyah, 2021; Irawan et al., 2020), tranfer pricing (Irawan et al., 2020; Wijaya \& Rahayu, 2021), siklus hidup perusahaan (Irawan \& Afif, 2020), diversifikasi perusahaan (Aryotama \& Firmansyah, 2019), strategi perusahaan (Aryotama \& Firmansyah, 2020b), pihak berelasi (Aryotama \& Firmansyah, 2020a) dan konsentrasi pelanggan (Aryotama \& Firmansyah, 2019).

Karakteristik perusahaan merupakan indikasi adanya perusahaan untuk melakukan penghindaran pajak. Salah satu karakteristik perusahaan yang paling mudah untuk oleh investor dan calon investor dalah ukuran perusahaan. Ukuran perusahaan biasanya dikaitkan dengan capaian laba dan capaian penjualan dalam satu periode. Oleh karena itu, sejalan dengan ukuran perusahaan, karakteristik perusahaan lainnya yang terkait adalah profitabilitas. Perusahaan yang memiliki skala besar semakin menjadi pusat perhatian pemerintah atau melakukan penghindaran pajak (Kurniasih \& Sari, 2013). Perusahaan besar memiliki kemampuan untuk menangguhkan pendapatan periode kini menjadi pendapatan periode mendatang dengan menggunakan metode akuntansi tertentu sehingga keuntungan yang dilaporkan pada tahun tersebut lebih rendah daripada yang seharusnya (Watts \& Zimmerman, 1990). Merslythalia \& Lasmana (2016) menyatakan bahwa perusahaan dengan aset yang besar biasanya memiliki transaksi yang lebih kompleks sehingga memungkinkan perusahaan untuk memanfaatkan celah dalam peraturan perundangan untuk melakukan penghindaran pajak. V. R. Putri \& Putra (2017), 


\section{EDUCORETAX}

Volume 1 No. 4, Desember 2021

dan Swingly \& Sukartha (2015) menyimpulkan bahwa ukuran perusahaan berpengaruh negatif terhadap penghindaran pajak. Wardani \& Khoiriyah (2018) menyimpulkan bahwa ukuran perusahaan berpengaruh positif terhadap penghindaran pajak, sedangkan Annisa et al. (2017) dan Fitria \& Handayani (2019) menunjukkan bahwa ukuran perusahaan tidak terkait dengan penghindaran pajak. Hasil pengujian penelitian sebelumnya yang inkonsisten, mengakibatkan perlunya pengujian kembali ukuran perusahaan terhadap penghindaran pajak.

Perusahaan dapat menjamin keberlangsungannya di masa depan dengan menghasilkan laba yang tinggi (Kieso et al., 2018). Kinerja perusahaan yang tinggi menunjukkan bahwa perusahaan tersebut dianggap stabil (Puspitasari et al., 2021). Di sisi lain, perusahaan yang memiliki laba yang tinggi akan dikenakan kewajiban pajak yang besar (Puspitasari et al., 2021). Perusahaan yang memiliki sumber daya yang besar cenderung untuk berupaya menurunkan pembayaran pajak dengan melakukan tindakan penghindaran pajak. Darmawan \& Sukartha (2014), Dwiyanti \& Jati (2019), Kurniasih \& Sari (2013), Puspitasari et al. (2021), V. R. Putri \& Putra (2017), Yulianty et al. (2021) menemukan bahwa profitabilitas tinggi dalam perusahaan mengindikasikan tindakan penghindaran pajak yang dilakukan oleh perusahaan tersebut. Sementara itu, Dewinta \& Setiawan (2016) menyimpulkan bahwa profitabilitas berpengaruh negatif terhadap penghindaran pajak. Adanya hasil pengujian yang masih belum konslusif dalam penelitian sebelumnya mendorong leverage tidak berpengaruh terhadap penghindaran pajak.

Penelitian ini bertujuan untuk menguji pengaruh ukuran perusahaan dan profitabilitas terhadap penghindaran pajak. Ukuran perusahaan dan profitabilitas merupakan karakteristik perusahaan yang saling berkaitan. Ukuran perusahaan yang semakin tinggi cenderung dituntut untuk mendapatkan laba yang besar. Selain itu, perusahaan yang besar biasanya memiliki sumber daya, sistem informasi dan sistem prosedur operasi yang lebih baik dalam menunjang peningkatan kinerja perusahaan. Data perusahaan dalam penelitian ini menggunakan data perusahaan sektor konsumsi yang terdaftar di Bursa Efek Indonesia dan menggunakan data sebelum pandemi covid19. Terkait dengan hal tersebut, perusahaan sektor konsumsi menggunakan tingkat penjualan dalam menghasilkan pendapatan utama. Pandemi covid19 yang terjadi tahun 2020 mengakibatkan perusahaan mengalami penurunan kinerja perusahaan, sehingga otoritas pajak di Indonesia memberikan pelonggaran atas kewajiban perpajakan di tahun tersebut (Firmansyah \& Ardiansyah, 2020). Oleh karena itu, penelitian ini relevan untuk kondisi normal diluar dari kondisi yang terjadi pada era pandemic covid19.

Penelitian ini juga menggunakan pertumbuhan penjualan sebagai variabel kontrol. Pertumbuhan penjualan termasuk dalam karakteristik perusahaan yang erat kaitannya dengan ukuran perusahaan dan profitabilitas. Informasi pertumbuhan penjualan pada perusahaan sektor konsumsi sangat terkait dengan tingkat laba yang dihasilkan dalam suatu periode dan dapat dikaitkan dengan perusahaan dengan nilai aset tertentu. Tanjaya \& Nazir (2021), Tebiono \& Sukadana (2019) dan Za'imah et al. (2020) menemukan bahwa pertumbuhan penjualan berhubungan dengan aktivitas penghindaran pajak perusahaan. Adanya target penjualan yang lebih tinggi tahun berjalan dibandingkan dengan tahun sebelumnya merupakan indikasi penghindaran pajak yang dilakukan manajer dalam aktivitas operasi perusahaan.

Penelitian ini diharapkan dapat memberikan kontribusi dalam mengembangkan literatur terkait dengan perpajakan dan akuntansi keuangan. Selain itu, dalam kondisi normal, penelitian ini juga diharapkan dapat memberikan manfaat kepada Otoritas Pajak di Indonesia terkait dengan perbaikan kebijakan perpajakan khususnya pajak penghasilan badan.

\section{KAJIAN PUSTAKA}

Konflik keagenan terjadi karena adanya perbedaan kepentingan antara manajer dan pemegang saham (Jensen \& Meckling, 1976). Dalam mengelola perusahaan, manajer memiliki 


\section{EDUCORETAX}

Volume 1 No. 4, Desember 2021

keunggulan terkait dengan informasi yang lebih lengkap dibandingkan dengan pemegang saham Manajemen (Firmansyah, Jadi, \& Sukarno, 2021; Scott, 2015). Selain itu, manajer memiliki diskresi untuk mempengaruhi angka-angka akuntansi dalam laporan keuangan (Scott, 2015). Pemegang saham selaku pemili perusahaan tidak memiliki informasi yang cukup untuk mengawasi kinerja manajer. Salah satu aktivitas yang dijalankan oleh manajer adalah penghindaran pajak.

Perusahaan yang mapan dan besar biasanya ditunjukkan dengan dengan jumlah aset yang besar (Firmansyah, Jadi, Febrian, et al., 2021; Rosyida et al., 2020). Perusahaan besar pada umumnya memiliki sumber daya yang besar termasuk pegawai yang handal. Perusahaan yang besar cenderung lebih mudah untuk melakukan perencanaan pajak. Kepemilikan perusahaan atas sumber daya yang memadai mendorong manajer untuk melakukan penghematan pajak dengan memanfaatkan celah peraturan perundangan. Selain itu, perusahaan besar memiliki perencanaan yang baik dalam menghasilkan laba tertentu dibandingkan dengan perusahaan yang lebih kecil. Kondisi ini sejalan dengan temuan Wardani \& Khoiriyah (2018) bahwa ukuran perusahaan yang besar cenderung untuk melakukan penghindaran pajak. Laba yang besar dan stabil menjadi motivasi manajer untuk melakukan penghindaran pajak karena perusahaan harus menanggung beban pajak yang besar. Oleh karena itu, penggunaan sumber daya yang dimiliki oleh perusahaan dapat digunakan oleh manajer dalam menekan beban pajak perusahaan terkait dengan maksimalisasi kinerja perusahaan.

$\mathrm{H}_{1}$ : Perusahaan dengan ukuran perusahaan yang besar memiliki kecenderungan untuk melakukan penghindaran pajak

Informasi asimetri antara manajer dan pemegang saham menunjukkan bahwa manajer memiliki informasi yang lebih sempurna dibandingkan dengan pemegang saham (Firmansyah, Jadi, \& Sukarno, 2021), karena manajer mengelola perusahaan secara langsung. Manajer dituntut untuk mencapai kinerja operasi yang tinggi. Terkait dengan hal tersebut manajer memiliki kebijakan untuk menjalankan motif-motif jangka pendek tertentu tertentu seperti mendapatkan bonus yang tinggi (Saksessia \& Firmansyah, 2020). Selain itu, tingkat keuntungan menunjukkan dengan strategi yang dijalankan oleh manajer terkait dengan strategi bisnis perusahaan dan investasi di masa depan (Aryotama \& Firmansyah, 2020b; Firmansyah \& Triastie, 2020). Namun, adanya kewajiban perpajakan untuk setiap perusahaan mengakibatkan manajer berupaya untuk meminimalisir beban pajak dengan cara-cara yang tidak melanggar ketentuan peraturan perundangan.

Di satu sisi, manajer yang memiliki capaian kinerja operasi yang tinggi dianggap sukses dalam mengelola perusahaan. Di sisi lain, capain kinerja operasi yang tinggi tersebut diharapkan dapat memberikan manfaat kepada manajer dalam bentuk bonus yang diterimanya (Jananto \& Firmansyah, 2019). Dengan melakukan penghindaran pajak, manajer mengharapkan jumlah bonus yang lebih besar akibat beban pajak yang dikurangkan dari laba operasi menjadi lebih kecil. Darmawan \& Sukartha (2014), Dwiyanti \& Jati (2019), Kurniasih \& Sari (2013), Puspitasari et al. (2021), V. R. Putri \& Putra (2017), dan Yulianty et al. (2021) menemukan bahwa profitabilitas yang tinggi mengindikasikan bahwa perusahaan tersebut melakukan penghindaran pajak. Profitabilitas perusahaan dipengaruhi oleh keuntungan yang diperoleh perusahaan dalam suatu periode, sehingga pajak yang harus dibayarkan akan bertambah ketika perusahaan memiliki profitabilitas tinggi. Manajer dapat menggunakan strategi dan sumber daya yang dimiliki perusahaan untuk dapat menekan beban pajak yang dibayarkan perusahaan kepada pemerintah.

$\mathrm{H}_{2}$ : Perusahaan dengan tingkat profitabilitas yang tinggi memiliki kecenderungan untuk melakukan penghindaran pajak

\section{METODE}




\section{EDUCORETAX}

Volume 1 No. 4, Desember 2021

Penelitian ini menggunakan data sekunder yang diperoleh dari www.idx.co.id berupa data laporan keuangan perusahaan manufaktur sub sektor konsumsi tahun 2017-2019. Dalam penelitian ini, pengambilan sampel dilakukan secara purposive sampling dengan kriteria sebagai berikut:

Tabel 1 Pemilihan Sampel Penelitian

\begin{tabular}{lr}
\hline Kriteria & Jumlah \\
\hline Emiten sektor barang konsumsi di BEI per 30 November 2020 & 52 \\
Emiten yang melakukan initial public offering (IPO) setelah 1 Januari 2017 & -20 \\
Emiten yang memiliki laporan keuangan tahunan dengan informasi tidak lengkap selama periode & \\
2017-2019 & 0 \\
Data perusahaan yang dapat digunakan dalam penelitian & 32 \\
Jumlah tahun penelitian & 3 \\
Total sampel & 96 \\
\hline
\end{tabular}

Sumber: data diolah

Penghindaran pajak merupakan variabel dependen dalam penelitian ini. Proksi penghindaran pajak dalam penelitian ini menggunakan Cash Effective Tax Rate (CETR), mengikuti proksi yang digunakan oleh Ferdiawan \& Firmansyah (2017), Ilmiani \& Sutrisno (2014), Wardani \& Khoiriyah (2018). CETR menunjukkan tingkat kepatuhan pajak perusahaan, sehingga penghindaran pajak memiliki nilai yang terbalik dengan CETR.

Dimana:

$$
\text { CashETR }=\frac{\text { Cash Tax Paid }}{\text { Pretax Income }}
$$

Cash ETR : Cash Effective Tax Rate perusahaan i pada tahun $\mathrm{t}$

Cash Tax Paid: jumlah kas yang dibayarkan untuk kewajiban perpajakan oleh perusahaan i pada tahun $\mathrm{t}$

Pretax Income: laba sebelum pajak perusahaan i pada tahun $\mathrm{t}$

Selanjutnya, ukuran perusahaan dan profitabilitas merupakan variabel independen dalam penelitian ini. Ukuran perusahaan dalam penelitian ini menggunakan proksi sebagaimana Annisa et al. (2017), V. R. Putri \& Putra (2017), Swingly \& Sukartha (2015), Wardani \& Khoiriyah (2018) yaitu:

Ukuran perusahaan = logaritma natural total aset

Proksi profitabilitas dalam penelitian ini menggunakan Return On Asset (ROA) sebagaimana Dwiyanti \& Jati (2019), Puspitasari et al. (2021), dan Yulianty et al. (2021).

$$
\mathrm{ROA}=\frac{\text { Net Income }}{\text { Total Assets }}
$$

Penelitian ini juga menggunkaan variabel kontrol yaitu pertumbuhan penjualan. Proksi pertumbuhan penjualan mengikuti Tanjaya \& Nazir (2021), Tebiono \& Sukadana (2019), Za'imah et al. (2020).

$$
\mathrm{SGR}=\frac{\text { Sales }_{\mathrm{t}}-\text { Sales }_{\mathrm{t}-1}}{\text { Sales }_{\mathrm{t}-1}}
$$

Analisis regresi linear berganda untuk data panel digunakan untuk menguji hipotesis dalam penelitian ini. Model penelitian ini adalah sebagai berikut:

Di mana:

$$
\text { TAVOID }_{i t}=\beta 0+\beta 1 \text { SIZE }_{i t}+\beta 2 \mathrm{ROA}_{i t}+\beta 3 \mathrm{SGR}_{\mathrm{it}}+\varepsilon_{\mathrm{it}}
$$

TAVOID $_{\text {it }} \quad$ : Penghindaran pajak perusahaan i pada tahun $\mathrm{t}$

SIZE $_{\text {it }} \quad$ : Ukuran perusahaan i pada tahun $\mathrm{t}$

$\mathrm{ROA}_{\text {it }} \quad$ : Profitabilitas perusahaan i pada tahun $\mathrm{t}$

$\mathrm{SGR}_{\text {it }} \quad$ : Pertumbuhan penjualan perusahaan i pada tahun $\mathrm{t}$

\section{HASIL DAN PEMBAHASAN}

Statistik deskriptif dari variabel-variabel yang digunakan dalam penelitian ini terdapat 
EDUCORETAX

Volume 1 No. 4, Desember 2021

dalam Tabel 2 sebagai berikut:

Tabel 2 Statistik Deskriptif

\begin{tabular}{ccrrrrr}
\hline Uraian & \multicolumn{1}{c}{ Mean } & Med. & \multicolumn{1}{c}{ Std. Dev. } & \multicolumn{1}{c}{ Min. } & \multicolumn{1}{c}{ Max. } & \multicolumn{1}{l}{ Obs } \\
\hline CETR & 0.361 & 0.254 & 0.718 & 0.0001 & 6.935 & 96 \\
SIZE & 28.73 & 28.48 & 1.629 & 25.73 & 32.201 & 96 \\
PROF & 0.103 & 0.073 & 0.146 & -0.176 & 0.921 & 96 \\
SDR & 0.051 & 0.050 & 0.127 & -0.472 & 0.500 & 96 \\
\hline
\end{tabular}

Sumber: data diolah

Selanjutnya, ringkasan hasil uji hipotesis dengan menggunakan fixed effect model adalah sebagai berikut:

Tabel 3 Ringkasan Hasil Uji Hipotesis

\begin{tabular}{ccccc}
\hline Var. & Coeff. & t-Stat. & Prob. & \\
\hline C & -7.265 & -6.782 & 0.000 & $* * *$ \\
SIZE & -0.732 & -3.988 & 0.000 & $* * *$ \\
PROF & -0.431 & -3.204 & 0.001 & $* * *$ \\
SGR & 0.269 & 7.193 & 0.000 & $* * *$ \\
R2 & 0.798 & & & \\
Adj. R2 & 0.685 & & & \\
F-stat. & 7.076 & & & \\
Prob(F-stat.) & 0 & & & \\
\hline
\end{tabular}

Sumber: data diolah

Keterangan: $* * *)$ berpengaruh pada tingkat signifikansi $1 \%$.

Pengaruh Ukuran Perusahaan Terhadap Penghindaran Pajak

Hasil pengujian hipotesis menunjukan bahwa ukuran perusahaan berpengaruh positif terhadap pengindaran pajak. Penelitian ini mengkonfirmasi hasil pengujian yang dilakukan oleh Wardani \& Khoiriyah (2018), namun tidak mengkonfirmasi hasil pengujian yang dilakukan oleh Annisa et al. (2017), Fitria \& Handayani (2019), V. R. Putri \& Putra (2017), Swingly \& Sukartha (2015). Perusahaan besar memiliki sumber daya yang memadai dalam melakukan tindakan penghindaran pajak seperti sumber daya manusia, sistem informasi, proses bisnis. Tindakan penghindaran pajak merupakan tindakan penghematan pajak yang dilakukan oleh perusahaan tanpa melanggar ketentuan perpajakan.

Selain itu, perusahaan besar biasanya merupakan perusahaan yang telah mencapai tahap kedewasaan, sehingga perusahaan memiliki strategi jangka panjang yang telah direncanakan dengan baik untuk tetap mempertahankan kinerjanya. Penghindaran pajak merupakan tindakan yang dilakukan oleh perusahaan dalam satu periode dengan tujuan untuk mencapai laba perusahaan tertentu. Berdasarkan strategi dan rencana perusahaan ke depan, perusahaan memanfaatkan sumber daya yang ada untuk dapat menekan biaya yang harus dikeluarkan oleh perusahaan termasuk kewajiban perpajakan kepada pemerintah. Perusahaan besar tetap mematuhi ketentuan perpajakan dengan baik walaupun adanya indikasi penghindaran pajak. Perusahaan besar berusaha untuk menyelaraskan pencapaian strategi yang dsirencanakan dengan upaya penghematan pajak dalam rangka menekan biaya perusahaan seminimal mungkin.

\section{Pengaruh Profitabilitas terhadap Penghindaran Pajak}

Hasil pengujian menunjukkan bahwa profitabilitas berpengaruh positif terhadap penghindaran pajak. Hasil pengujian ini sejalan dengan Darmawan \& Sukartha (2014), Dwiyanti \& Jati (2019), Kurniasih \& Sari (2013), Puspitasari et al. (2021), V. R. Putri \& Putra (2017), dan Yulianty et al. (2021), namun tidak sejalan dengan Dewinta \& Setiawan (2016). Tujuan manajer mendapatkan kinerja yang baik untuk mencapai tujuan jangka pendek dan jangka panjang. Manajer dianggap berhasil apabila dapat mengelola perusahaan dengan baik. Salah satu indikasinya adalah mencapai tingkat laba yang semakin tinggi. Pemilik perusahaan mengharapkan bahwa perusahaan dapat terjamin keberlangsungannya dan tetap stabil dalam 


\section{EDUCORETAX}

Volume 1 No. 4, Desember 2021

menjalankan aktivitasnya.

Pemilik perusahaan dapat menanggung beban keagenan yang lebih tinggi dengan catatan bahwa manajer berhasil dalam mengelola perusahaan. Adanya asimetri informasi antara manajer dan pemegang saham dimanfaatkan manajer untuk mendapatkan bonus yang tinggi. Manajer menggunakan strategi perencanaan pajak dalam memenuhi kewajiban pajak perusahaan kepada pemerintah. Walaupun perusahaan mendapatkan laba yang tinggi, tidak berarti bahwa perusahaan akan menanggung beban pajak yang tinggi. Manajer dapat memanfaatkan celah peraturan perpajakan untuk meminimalisir kewajiban pajak perusahaan kepada pemerintah. Manajer berupaya untuk menggunakan keahlian dan sumber daya yang tersedia dalam perusahaan untuk menjalankan strategi tersebut. Di sisi lain, manajer juga harus menjaga reputasinya dalam menjalankan strategi perusahaan di masa depan baik strategi bisnis maupun investasi perusahaan dengan meminimalisir kewajiban pajak perusahaan setiap periode.

\section{PENUTUP}

\section{Simpulan}

Perusahaan yang besar dan profitabilitas yang tinggi cenderung untuk melakukan penghindaran pajak. Penelitian ini membuktikan bahwa ukuran perusahaan dan profitabilitas merupakan indikasi yang simultan atas aktivitas penghindaran pajak yang dilakukan oleh perusahaan.

\section{Saran}

Penelitian ini hanya menggunakan data perusahaan sektor barang konsumsi sehingga tidak mencerminkan kondisi untuk seluruh perusahaan sektor manufaktur. Selain itu, horison waktu yang digunakan dalam penelitian ini hanya 3 tahun yaitu tahun 2017-2019. Oleh karena itu, penelitian selanjutnya dapat menggunakan data perusahaan yang tercakup dalam sektor manufaktur dan horison waktu yang lebih panjang untuk mendapatkan hasil penelitian yang lebih baik. Penelitian ini mengindikasikan bahwa otoritas perpajakan di Indonesia dapat melihat karakteristik perusahaan tertentu terkait dengan kebijakan penghindaran pajak. Selain itu, otoritas pajak di Indonesia dapat berkoordinasi dengan otoritas pengawas pasar modal di Indonesia terkait dengan aktivitas penghindaran pajak dan perlindungan investor di pasar modal.

\section{DAFTAR PUSTAKA}

Annisa, A., Taufik, T., \& Hanif, R. A. (2017). Pengaruh return on asset, leverage, ukuran perusahaan dan koneksi politik terhadap penghindaran pajak (studi empiris pada perusahaan manufaktur yang terdaftar di BEI periode tahun 2012-2015). Jurnal Online Mahasiswa (JOM) Bidang Ilmu Ekonomi, 4(1), 685-698. https://jom.unri.ac.id/index.php/JOMFEKON/article/view/12396

Arham, A., Firmansyah, A., Nor, A. M. E., \& Vito, B. (2020). A bibliographic study on tax avoidance research in Indonesia. International Journal of Psychosocial Rehabilitation, 24(7), 9526-9554. https://www.psychosocial.com/article/PR270956/19446/

Aryotama, P., \& Firmansyah, A. (2019). The effect of corporate diversification, customer concentration on tax avoidance in Indonesia. Jurnal Akuntansi Dan Bisnis, 19(2), 117125. https://doi.org/10.20961/jab.v19i2.475

Aryotama, P., \& Firmansyah, A. (2020a). The association between related party transaction and tax avoidance in Indonesia. AFEBI Accounting Review, 4(02), 117. https://doi.org/10.47312/aar.v4i02.243

Aryotama, P., \& Firmansyah, A. (2020b). The effect of business strategy on tax avoidance in Indonesia's consumer goods industry. In Public Sector Accountants and Quantum Leap: 
How Far We Can Survive in Industrial Revolution 4.0? (pp. 235-239). Routledge. https://doi.org/10.1201/9780367822965

Darmawan, I. G. H., \& Sukartha, I. M. (2014). Pengaruh penerapan corporate governance, leverage, return on assets, dan ukuran perusahaan pada penghindaran pajak. E-Jurnal Akuntansi Universitas Udayana, 9(1), 143-161. https://ojs.unud.ac.id/index.php/Akuntansi/article/view/8635

Dewinta, I. A. R., \& Setiawan, P. E. (2016). Pengaruh ukuran perusahaan, umur perusahaan, profitabilitas, leverage, dan pertumbuhan penjualan terhadap tax avoidance. E-Jurnal Akuntansi Universitas Udayana, 14(3), 1584-1615. https://ojs.unud.ac.id/index.php/Akuntansi/article/view/16009

Dwiyanti, I. A. I., \& Jati, I. K. (2019). Pengaruh profitabilitas, capital intensity, dan inventory intensity pada penghindaran pajak. E-Jurnal Akuntansi, 27(3), 2293-2321. https://doi.org/10.24843/EJA.2019.v27.i03.p24

Falbo, T. D., \& Firmansyah, A. (2018). Thin capitalization, transfer pricing aggresiveness, penghindaran pajak. Indonesian Journal of Accounting and Governance, 2(1), 1-28. https://doi.org/10.36766/ijag.v2i1.11

Falbo, T. D., \& Firmansyah, A. (2021). Penghindaran pajak di Indonesia: multinationality dan manajemen laba. Bisnis-Net Jurnal Ekonomi Dan Bisnis, 4(1), 94-110. https://doi.org/10.46576/bn.v4i1.1325

Ferdiawan, Y., \& Firmansyah, A. (2017). Pengaruh political connection, foreign activity, dan, real earnings management ter-hadap tax avoidance. Jurnal Riset Akuntansi Dan Keuangan, 5(3), 1601-1624. https://doi.org/10.17509/jrak.v5i3.9223

Firmansyah, A., \& Ardiansyah, R. (2020). Bagaimana praktik manajemen laba dan penghindaran pajak sebelum dan setelah pandemi covid19 di Indonesia? Bina Ekonomi, 24(2), 31-51. https://doi.org/10.26593/be.v24i1.5075.87-106

Firmansyah, A., Jadi, P. H., Febrian, W., \& Sismanyudi, D. (2021). Pengaruh tata kelola perusahaan dan ukuran perusahaan terhadap pengungkapan emisi karbon di Indonesia. 16(2), 303-320. https://doi.org/10.25105/jipak.v16i2.9420

Firmansyah, A., Jadi, P. H., \& Sukarno, R. S. (2021). Bagaimana respon investor terhadap kepemilikan saham oleh CEO? Jurnal Online Insan Akuntan, 4(1), 15-28. https://ejournalbinainsani.ac.id/index.php/JOIA/article/view/1476

Firmansyah, A., \& Triastie, G. A. (2020). The role of corporate governance in emerging market: Tax avoidance, corporate social responsibility disclosures, risk disclosures, and investment efficiency. Journal of Governance and Regulation, 9(3), 8-26. https://doi.org/10.22495/jgrv9i3art1

Fitria, G. N., \& Handayani, R. (2019). Tax avoidance: studi empiris pada perusahaan manufaktur sektor barang konsumsi di Indonesia. Monex : Journal Research Accounting Politeknik Tegal, 8(1), 251. https://doi.org/10.30591/monex.v8i1.1263

Hidayat, W. W. (2018). Pengaruh profitabilitas, leverage dan pertumbuhan penjualan terhadap penghindaran pajak. Jurnal Riset Manajemen Dan Bisnis (JRMB), 3(1), 19-26.

Ilmiani, A., \& Sutrisno, C. R. (2014). Pengaruh tax avoidance terhadap nilai perusahaan dengan transparansi perusahaan sebagai variabel moderating. Jurnal Ekonomi Dan Bisnis, 14(1), 30-39. https://doi.org/10.31941/jebi.v14i1.194

Irawan, F., \& Afif, A. R. (2020). Does firms' life cycle influence tax avoidance? evidence from Indonesia. International Journal of Innovation, Creativity and Change, 14(1), 1211-1229. https://www.ijicc.net/images/Vol_14/Iss_1/14118_Irawan_2020_E_R.pdf

Irawan, F., Kinanti, A., \& Suhendra, M. (2020). The impact of transfer pricing and earning $\begin{array}{llll}\text { management } & \text { tax avoidance. } & \text { 32(3), }\end{array}$ https://www.iratde.com/index.php/jtde/article/view/1229 
Jananto, A. E., \& Firmansyah, A. (2019). The effect of bonuses, cost of debt, tax avoidance, and corporate governance on financial reporting aggressiveness: evidence from Indonesia. International Journal of Innovation, Creativity and Change, 7(5), 280-302.

Jensen, M. C., \& Meckling, W. H. (1976). Theory of the firm: Managerial behavior, agency costs and ownership structure. Journal of Financial Economics, 3(4), 305-360. https://doi.org/10.1016/0304-405X(76)90026-X

Kieso, D. E., Weygandt, J. J., \& Warfield, T. D. (2018). Intermediate accounting: IFRS Edition, 3rd Edition. John Wiley \& Sons, Inc. https://www.google.co.id/books/edition/Intermediate_Accounting/VXH5twEACAAJ?hl $=$ en

Kurniasih, T., \& Sari, M. R. (2013). Pengaruh return on assets, leverage, corporate governance, ukuran perusahaan dan kompensasi rugi fiskal pada tax avoidance. Buletin Studi Ekonomi, 18(1), 58-66. https://ojs.unud.ac.id/index.php/bse/article/view/6160

Mankiw, N. G. (2012). Principles of economics sixth edition. South-Western Cengage Learning.

Manurung, J. T. P. (2020). Praktik penghindaran pajak di Indonesia. https://pajak.go.id/id/artikel/praktik-penghindaran-pajak-di-indonesia

Merslythalia, D. R., \& Lasmana, M. S. (2016). Komisaris independen, dan kepemilikan institusional terhadap tax avoidance. Jurnal Ilmiah Akuntansi Dan Bisnis, 11(2), 117-124. https://ojs.unud.ac.id/index.php/jiab/article/view/28339

Mulyani, S., Wijayanti, A., \& Masitoh, E. (2018). Pengaruh corporate governance terhadap tax avoidance (perusahaan pertambangan yang terdaftar di BEI). Jurnal Riset Akuntansi Dan Bisnis Airlangga, 3(1), 322-340. https://doi.org/10.31093/jraba.v3i1.91

Pajriansyah, R., \& Firmansyah, A. (2017). Pengaruh leverage, kompensasi rugi fiskal dan manajemen laba terhadap penghindaran pajak. Keberlanjutan: Jurnal Manajemen Dan Jurnal Akuntansi, 2(1), 431-459. http://openjournal.unpam.ac.id/index.php/keberlanjutan/article/view/571

Permata, A. D., Nurlaela, S., \& Wahyuningsih, E. M. (2018). Pengaruh size, age, profitability, leverage dan sales growth terhadap tax avoidance. Jurnal Akuntansi Dan Pajak, 19(1), 10. https://doi.org/10.29040/jap.v19i1.171

Pramudya, T. A., Lie, C., Firmansyah, A., \& Trisnawati, E. (2021). Peran komisaris independen di indonesia: multinationality, tax haven, penghindaran pajak. Jurnalku, 1(3), 200-209. https://jurnalku.org/index.php/jurnalku/article/view/40

Puspitasari, D., Radita, F., \& Firmansyah, A. (2021). Penghindaran pajak di Indonesia: profitabilitas, leverage, capital intensity. Jurnal Riset Akuntansi Tirtayasa, 6(2), 138-152. https://doi.org/10.48181/jratirtayasa.v6i2.10429

Putri, R. D. (2018). Pengaruh corporate governance terhadap tax avoidance (studi empiris perusahaan sektor perbankan yang terdaftar di BEI tahun 2012-2016). Jurnal Ekonomi \& Bisnis Dharma Andalas, 20(2), 337-347. http://ojs.unidha.ac.id/index.php/edb_dharmaandalas/article/view/106

Putri, V. R., \& Putra, B. I. (2017). Pengaruh leverage, profitability, ukuran perusahaan dan proporsi kepemilikan institusional terhadap tax avoidance. Jurnal Ekonomi Manajemen Sumber Daya, 19(1), 1-11. https://doi.org/10.23917/dayasaing.v19i1.5100

Republik Indonesia. (2007). Undang-Undang Republik Indonesia Nomor 28 Tahun 2007 Tentang Perubahan Ketiga Atas Undang-Undang Nomor 6 Tahun 1983 Tentang Ketentuan Dan Um Tata Cara Perpajakan. https://www.dpr.go.id/dokjdih/document/uu/UU_2007_28.pdf

Rosyida, H., Firmansyah, A., \& Wicaksono, S. B. (2020). Volatilitas harga saham: leverage, ukuran perusahaan, pertumbuhan aset. JAS (Jurnal Akuntansi Syariah), 4(2), 196-208. 


\section{EDUCORETAX}

Volume 1 No. 4, Desember 2021

https://doi.org/10.46367/jas.v4i2.256

Saksessia, D., \& Firmansyah, A. (2020). The role of corporate governance on earnings quality from positive accounting theory framework. International Journal of Scientific and Technology Research, 9(1), 808-820. http://www.ijstr.org/final-print/jan2020/The-RoleOf-Corporate-Governance-On-Earnings-Quality-From-Positive-Accounting-TheoryFramework.pdf

Sari, M., \& Devi, H. P. (2018). Pengaruh corporate governance dan profitabilitas terhadap tax avoidance. Inventory: Jurnal Akuntansi, 2(2), 298-306. https://doi.org/10.25273/INVENTORY.V2I2.3289

Scott, W. R. (2015). Financial Accounting Theory (7th ed.). Pearson Canada.

Swingly, C., \& Sukartha, I. M. (2015). Pengaruh karakter eksekutif, komite audit, ukuran perusahaan, leverage dan sales growth pada tax avoidance. E-Jurnal Akuntansi Universitas Udayana, 10(1), 47-62.

Tanjaya, C., \& Nazir, N. (2021). Pengaruh profitabilitas, leverage dan ukuran perusahaan terhadap penghindaran pajak (tax avoidance). Jurnal Akuntansi Trisakti, 8(2), 189-208. https://doi.org/10.25105/jat.v8i2.9260

Tebiono, J. N., \& Sukadana, I. B. N. (2019). Faktor-faktor yang mempengaruhi tax avoidance pada perusahaan manufaktur yang terdaftar di BEI. Jurnal Bisnis Dan Akuntansi, 20(1a2), 121-130. https://doi.org/10.34208/jba.v21i1a-2.749

Victoria, A. O. (2020). Target pajak tak pernah tercapai dalam 10 tahun terakhir. https://katadata.co.id/agustiyanti/finansial/5e9a 4c3b2d85b/pengamat-target-pajak-takpernah-tercapai-dalam-10-tahun-terakhir

Wardani, D. K., \& Khoiriyah, D. (2018). Pengaruh strategi bisnis dan karakteristik perusahaan terhadap penghindaran pajak. Akuntansi Dewantara, 2(1), 25-36. https://jurnal.ustjogja.ac.id/index.php/akuntansidewantara/article/view/2181

Watts, R. L., \& Zimmerman, J. L. (1990). Positive accounting theory: a ten year perspective. The Accounting Review, 65(1), 131-156. https://www.jstor.org/stable/247880

Wijaya, S., \& Rahayu, F. D. (2021). Pengaruh agresivitas transfer pricing, penggunaan negara lindung pajak, dan kepemilikan institusional terhadap penghindaran pajak. Jurnal Informasi, Perpajakan, Akuntansi, Dan Keuangan Publik, 16(2), 245. https://doi.org/10.25105/jipak.v16i2.9257

Yulianty, A., Khrisnatika, M. E., \& Firmansyah, A. (2021). Penghindaran pajak pada perusahaan pertambangan di indonesia: profitabilitas, tata kelola perusahaan, intensitas persediaan, leverage. Jurnal Pajak Indonesia, 5(1), 20-31. https://doi.org/10.31092/jpi.v5i1.1201

Za'imah, A., Sobarudin, M., Permatasari, N. I., Nabilah, Z. N., \& Holiawati, H. (2020). Pengaruh pertumbuhan penjualan dan umur perusahaan terhadap tax avoidance (Prosiding Webinar "Insentif Pajak Untuk Wp Terdampak Covid-19"). http://openjournal.unpam.ac.id/index.php/Proceedings/article/view/9930

Zia, I. K., Pratomo, D., \& Kurnia. (2018). Kepemilikan institusional dan multinationality dengan firm size dan leverage sebagai variabel kontrol terhadap tax avoidance. Jurnal Riset Akuntansi Kontemporer, 10(2), 67-73. https://doi.org/10.23969/jrak.v10i2.1369 